\title{
PEGylated systems in pharmaceutics
}

\author{
Article
}

Accepted Version

Porfiryeva, N. N., Moustafine, R. I. and Khutoryanskiy, V. V. (2020) PEGylated systems in pharmaceutics. Polymer Science Series C, 61 (1). pp. 62-74. ISSN 1811-2382 doi: https://doi.org/10.1134/S181123822001004X Available at https://centaur.reading.ac.uk/91652/

It is advisable to refer to the publisher's version if you intend to cite from the work. See Guidance on citing.

Published version at: https://link.springer.com/article/10.1134/S181123822001004X

To link to this article DOI: http://dx.doi.org/10.1134/S181123822001004X

Publisher: Springer

All outputs in CentAUR are protected by Intellectual Property Rights law, including copyright law. Copyright and IPR is retained by the creators or other copyright holders. Terms and conditions for use of this material are defined in the End User Agreement.

\section{www.reading.ac.uk/centaur}

\section{CentAUR}

Central Archive at the University of Reading

Reading's research outputs online 
УДК

ПЭГИЛИРОВАННЫЕ СИСТЕМЫ В ФАРМАЦЕВТИКЕ

() 2019 г. Н.Н. Порфирьева ${ }^{1}$, Р.И. Мустафин ${ }^{*}$,

В.В. Хуторянский ${ }^{1,2 *}$

${ }^{1}$ Казанский государственный медицинский университет, Институт Фармации, 420126 Казань, ул. Фатыха Амирхана 16

${ }^{2}$ Reading School of Pharmacy, University of Reading, Whiteknights, PO box 224, Reading RG66AD, United Kingdom

Поступила в редакцию

Принята в печать

Полиэтиленгликоль (ПЭГ) является водорастворимым полимером с уникальным набором физико-химических и биологических свойств. Данный обзор посвящен использованию ПЭГилирования для дизайна новых лекарственных форм и модификации биомолекул. В частности, рассмотрены особенности ПЭГилированных наночастиц, липосом, белков, ферментов, малых молекул лекарств и полиэлектролитов и их влияние на системную доставку лекарств, а также преодоление различных биологических барьеров и адгезию к слизистым тканям (мукоадгезию). 
E-mail: rouslan.moustafine@gmail.com (Мустафин Руслан Ибрагимович), v.khutoryanskiy@reading.ac.uk (Хуторянский Виталий Викторович)

Ключевые слова: медицинские полимеры, простые полиэфиры, коллоиды, биополимеры, полиэлектролиты

\section{PEGYLATED SYSTEMS IN PHARMACEUTICS}

\section{N. N. Porfiryeva ${ }^{1}$, R.I. Moustafine ${ }^{1 *}$, V.V. Khutoryanskiy ${ }^{1,2^{*}}$}

${ }^{1}$ Institute of Pharmacy, Kazan State Medical University, 16 Fatykh Amirkhan Street, 420126 Kazan, Russian Federation

${ }^{2}$ Reading School of Pharmacy, University of Reading, Whiteknights, PO box 224, Reading RG66AD, United Kingdom

Abstract. Polyethyleneglycol (PEG) is a water-soluble polymer with unique physicochemical and biological properties. This literature review is focused on the use of PEGylation process in the design of novel dosage forms and modification of biomolecules. In particular, the peculiarities of PEGylated nanoparticles, liposomes, proteins, enzymes, small drug molecules and polyelectrolytes, and their influence on systemic drug 
delivery, as well as overcoming of various biological barriers and adhesion to mucosal tissues (mucoadhesion) are considered.

Keywords: medical polymers, polyethers, colloids, biopolymers, polyelectrolytes

\section{ВВЕДЕНИЕ}

В настоящее время одним из путей повышения эффективности фармакотерапии является усовершенствование способов доставки лекарственных веществ (ЛВ). Перспективным направлением при этом является процесс модификации молекул различными полимерными соединениями. Так, в мировой практике накоплен опыт получения конъюгатов лекарств с помощью ПЭГилирования - присоединения инертной макромолекулы полиэтиленгликоля (ПЭГ). Данные конъюгаты ПЭГ с ЛВ обеспечивают не только лучшую переносимость, но также обладают улучшенным фармакокинетическим профилем, способствуют более глубокому проникновению молекул и обеспечивают дополнительную защиту от действия протеолитических ферментов. При этом безопасность использования ПЭГ в области создании систем доставки ЛВ подтверждена управлением по санитарному надзору за качеством пищевых продуктов и 
медикаментов США (US Food and Drug Administration, FDA) в качестве субстанции, разрешенной к использованию в медицине (производство лекарственных препаратов), продуктах питания и косметологии.

Данный обзор рассматривает физико-химические свойства полиэтиленгликоля, способы присоединения ПЭГ к различным материалам фармацевтического назначения, особенности поведения ПЭГилированных материалов в биологических системах, и их применение в фармацевтике.

\section{СИНТЕЗ И СВОЙСТВА ПОЛИЭТИЛЕНГЛИКОЛЯ}

Впервые полимеризация этилен оксида и получение ПЭГ были осуществлены Вюрцем в 1863 году в присутствии гидроксидов щелочных металлов или хлорида цинка [1]. Позже, Штаудингер и Швейцер синтезировали ПЭГ с различными молекулярными массами для вискозиметрических исследований в 1929 году. И уже в 1930 году было налажено производство ПЭГ путем присоединения этилен оксида к этиленгликолю в присутствии оснований (Рисунок 1).

Промышленный синтез ПЭГ в настоящее время проходят путем анионной полимеризации с раскрытием кольца этилен оксида, инициированной нуклеофильной атакой гидроксид-иона на эпоксидное кольцо [2]. Использование гликолей в качестве инициаторов является 
более предпочтительным при синтезе, т.к. при этом способе возможно получение ПЭГ с небольшой полидисперсностью.

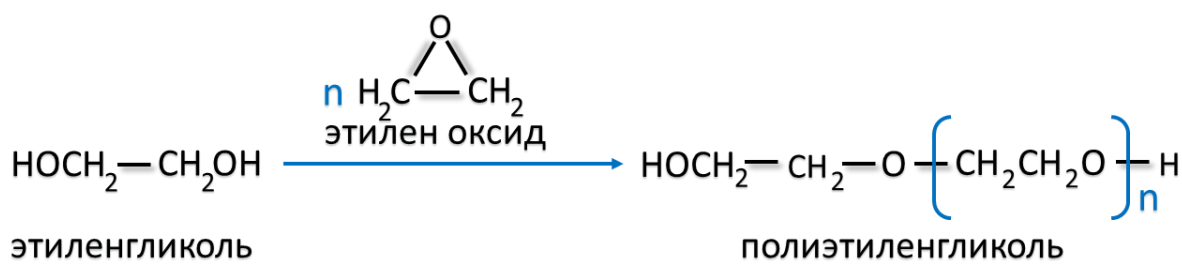

Рисунок 1. Схема синтеза ПЭГ.

Полимеры окиси этилена представляют собой водорастворимые материалы, молекулярная масса которых может достигать нескольких миллионов дальтон (Да). Полимеры с молекулярной массой (ММ) до 40 кДа принято называть полиэтиленгликолями (ПЭГ) [3,4], однако некоторые компании-производители химических реактивов и другие источники присваивают это название и материалам с более высокими диапазонами ММ (например, до 100 кДа). Полимеры с молекулярной массой выше 100 кДа принято называть полиэтиленоксидом (ПЭО)[4]. В зависимости от молекулярной массы полимеры окиси этилена могут представлять собой бесцветные жидкости, воскообразные либо твердые материалы. На рисунке 2 представлена зависимость температуры плавления ПЭГ от молекулярной массы. 


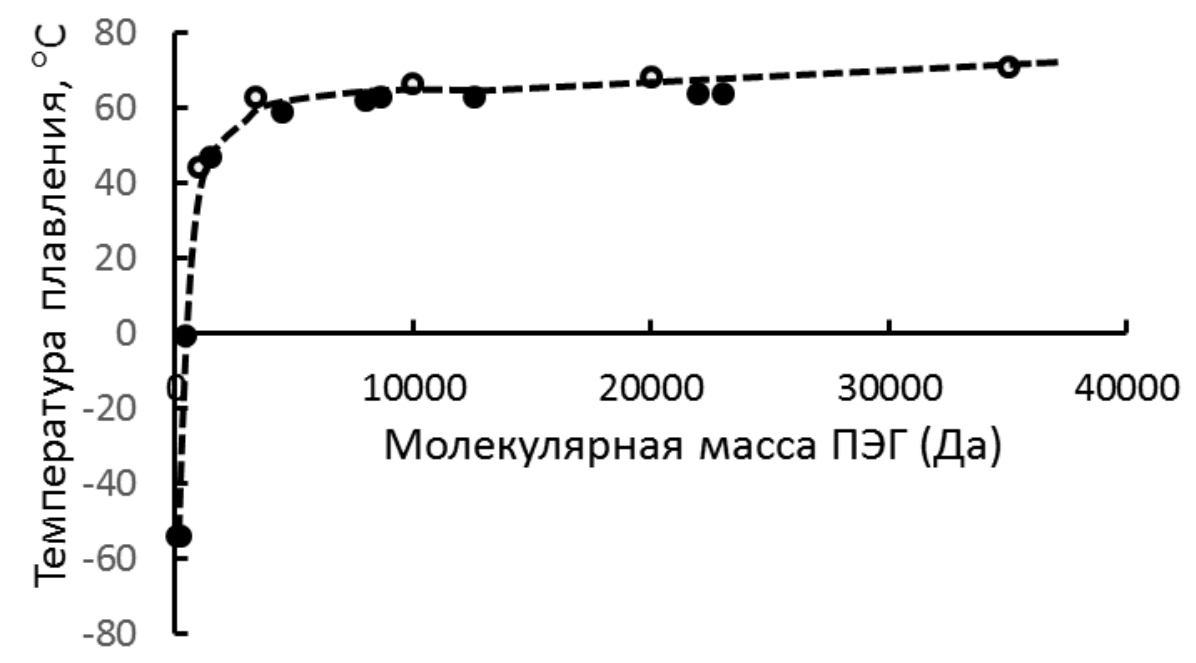

Рисунок 2. Зависимость температуры плавления ПЭГ от молекулярной массы. Эта зависимость построена по данным взятым из $[5,6]$.

Эта зависимость отражает переход от олигомерных ПЭГ (температура плавления которых зависит от молекулярной массы) к полимерной форме, у которой данная зависимость практически отсутствует приблизительно начиная с 5 кДа.

Данный полимер растворим во многих органических растворителях (бензоле, четыреххлористом углероде, хлороформе, диметилформамиде, ацетонитриле) и хорошо растворим в воде, причем степень его растворимости закономерно снижается с увеличением молекулярной массы [3,7]. 
В водных растворах ПЭГ является типичным неионным полимером, для которого характерна способность к образованию различного рода комплексов с некоторыми веществами полимерной и неполимерной природы. Например, в слабокислых средах ПЭГ может образовывать интерполимерные комплексы (ИПК) с поликарбоновыми кислотами, например, полиакриловой (ПАК) или полиметакриловой кислотой (ПМАК) посредством водородных связей [8-12]. Причем, данная способность к образованию ИПК проявляется лишь выше критической молекулярной массы ПЭГ, величина которой составляет 1000 Да [9]. Известны также комплексы ПЭГ и ПЭО с малыми молекулами, например, фенолами, ионами щелочных металлов, мочевиной и йодом [13]. При определенных соотношениях взаимодействующих компонентов, возможно также образование тройных комплексов, с участием двух полимеров и низкомолекулярных веществ. Например, Аксеновой с соавторами [14] показано образование тройных комплексов в системе ПМАК - ПЭО аминазин.

Интересной особенностью ПЭГ является также его способность к образованию комплексов-включения с циклодекстринами (ЦД). Отсутствие боковых заместителей в цепи, а также сравнительно гидрофобная природа $-\mathrm{CH}_{2}-\mathrm{CH}_{2}-\quad$ групп позволяет его 
макромолекулам нанизывать многочисленные циклические молекулы ЦД, что приводит к образованию агрегатов и гелей [15]. Структура образующихся при этом комплексов включения может быть представлена следующим образом (Рисунок 3).

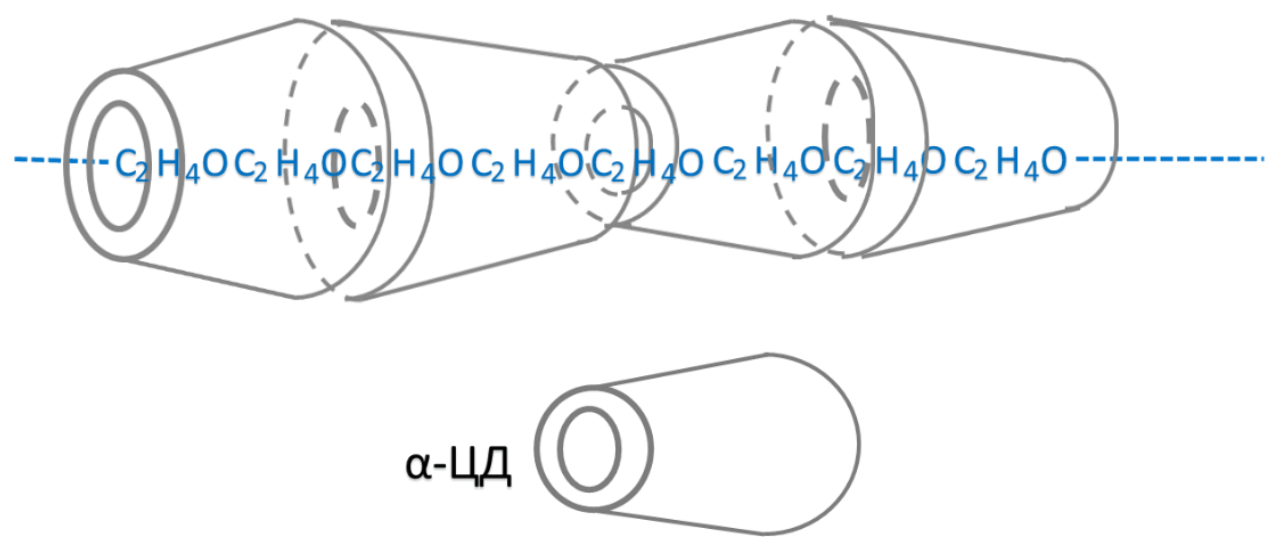

Рисунок 3. Структура комплексов, образующихся в смесях ПЭГ и $\alpha$-циклодекстрина. Перепечатано из [15] с разрешением American Chemical Society.

В литературе также имеются сведения об образовании гелей и многослойных пленок с участием ПЭГилированных коллоидных частиц на основе органосиликатов при вовлечении их в процессы комплексообразования с ПАК [16] и $\alpha$-ЦД [17].

Наличие в ПЭГ двух концевых гидроксильных групп дает возможность формировать макромолекулы как разветвленной, так и линейной структуры. Возможно получение сшитых форм ПЭГ, 
образующих в воде гидрогели [18], а также синтез ПЭГ с различными функциональными группами (малеимиды, метакрилаты, акрилаты и т.д.), которые образуются за счет модификации концевых гидроксильных групп [19]. Таким образом, благодаря структуре ПЭГ возможно получение и гетерофункциональных производных. Например, конъюгат ПЭГ, содержащий альдегидные и тиольные концевые группы, может быть получен путем полимеризации с 3,3диэтокси-1-пропанолом, который образует пропиональдегид после кислотного гидролиза; полимеризацию можно остановить с помощью метансульфонилхлорида с превращением в этилдитиокарбонат и свободный тиол [2,20,21].

Высокое содержание атомов кислорода в макромолекулах ПЭГ позволяет им связываться с несколькими молекулами воды. Подобный эффект влечет за собой формирование "водного облака" вокруг модифицированных молекул, благодаря чему значительно повышается их гидродинамический радиус [22].

ПЭГ является биосовместимым полимером с очень низкой иммуногенностью (способность вещества вызывать иммунный ответ), антигенностью (способность вещества связываться с антителами) и отсутствием токсичности. Он быстро и без структурных изменений выводится in vivo, при молекулярной массе около 20 кДа 
преимущественно удаляется с мочой, а при большем весе выводится вместе с мочой и калом [18]. Однако, низкомолекулярные олигомеры распадаются in vivo алкогольдегидрогеназой до токсичных метаболитов, ввиду чего в пищевых продуктах, косметике и фармацевтике используют ПЭГ с молекулярной массой выше 1 кДа, безопасность которых подтверждена многочисленными исследованиями [23].

Таким образом, регулируя вышеперечисленные свойства становится возможным подобрать оптимальные условия для реализации активности ЛВ и формирования систем доставки лекарств с улучшенными свойствами.

Первое упоминание об использовании метода ПЭГилирования в области доставки лекарственных веществ датируется 1977 годом, когда Davis и Abuchowski описали процесс присоединения ПЭГ к бычьему сывороточному альбумину [24]. Впоследствии, в 1990 году FDA утвердило первый модифицированный белковый продукт - Adagen®, представляющй собой П ПГлированный аденозиндеаминазы, направленный на лечение тяжелых форм вируса иммунодефицита [25]. С тех пор ПЭГ все больше привлекает внимание исследователей в качестве потенциального агента для создания систем с улучшенной доставкой лекарств. 


\section{ПЭГИЛИРОВАННЫЕ ЛИПОСОМЫ}

Долгие годы использование наночастиц для системного действия было ограничено тем, что иммунная система распознавала их, как чужеродные объекты и подвергала атаке. Однако, в начале 80-х и 90-х годов были успешно предприняты попытки покрытия наночастиц ПЭГом [26,27], благодаря чему увеличилось время их циркуляции в кровотоке. Уже в 1995 году FDA одобрило первый препарат на основе ПЭГилированных липосом - Doxil®. Липосомы Doxil «Stealth®» увеличивают биодоступность доксорубицина в 90 раз выше в течение 1 недели после инъекции, при этом увеличивается время циркуляции в крови и период полувыведения (3-4 дня) [28]. Положительные свойства ПЭГилированных липосом связаны с особенностью их строения (Рисунок 4). Липосомы состоят из фосфолипидов, представляющих собой дифильные молекулы, имеющие гидрофильную полярную головку и гидрофобные неполярные углеводородные цепи. Фосфолипидные молекулы способны образовывать в воде бислойные липидные мембраны [29]. Соответственно, водорастворимые ЛВ могут включаться во внутреннее водное пространство липосом, a гидрофобные в липидный бислой. ПЭГ, включенный в липидный бислой, образует гидратированную оболочку, которая надежно 
защищает липосомы от агрегации и фагоцитоза, тем самым избегая преждевременного высвобождения ЛВ во время циркуляции [30,31]. Более того, оболочка из ПЭГ способствует снижению адсорбции опсонинов, таких как комплемент С3a и $\mathrm{C} 3 \mathrm{~b}$, фибронектин и иммуноглобулин (преимущественно класса $\mathrm{G}$ ) на поверхности липосом $[32,33]$.

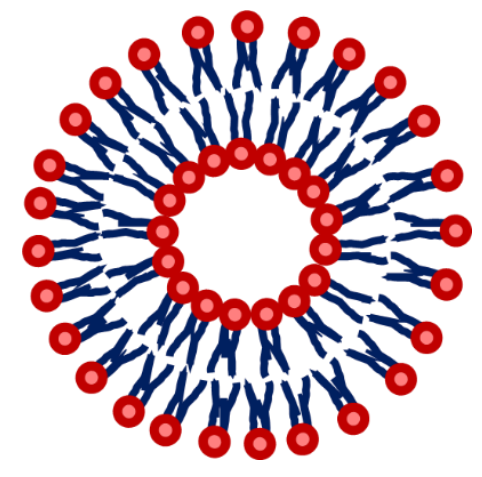

A

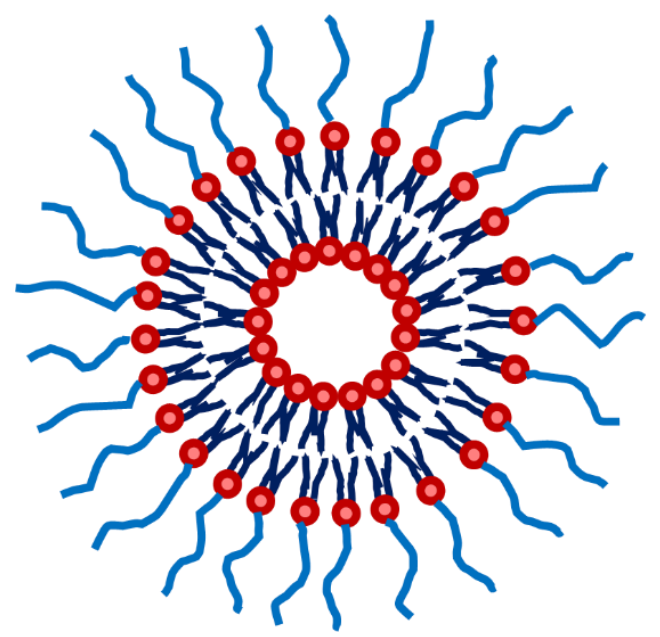

Б

Рисунок 4. Строение обычных липосом (А) и липосом с ПЭГилированной поверхностью (Б).

ПЭГилирование липосом может быть достигнуто различными способами: физическим адсорбированием полимера на поверхности пузырьков, ковалентным присоединением реакционноспособных ПЭГпроизводных к поверхности предварительно полученных липосом или включением ПЭГ-липидного конъюгата вместе с другими 
фосфолипидами во время получения липосом $[32,34]$. В клинической практике широко используется метод закрепления полимера в липосомальной мембране через ПЭГилированный липид; одним из $\begin{array}{lllll}\text { таких примеров является конъюгат } & \text { ПЭГ }\end{array}$ дистеароилфосфатидилэтаноламином (ДСФЭА) [35,36].

Важными параметрами при получении ПЭГилированных систем являются молекулярная масса и структура фрагмента ПЭГ, которые должны быть связаны с липосомой. При увеличении молекулярной массы ПЭГ с 750 Да в ПЭГилированных липосомах наблюдается их более длительная циркуляция в крови. Соответственно, увеличение длины цепи ПЭГ дает повышение времени циркуляции при системном введении. Одним из таких примеров является использование ПЭГилированных липосом с молекулярным весом 1,9 и 5 кДа, состоящих из сфингомиелина/яичного фосфатидилхолина/ холестерола/ДСФЭА-ПЭГ, которые продемонстрировали увеличение времени пребывания в крови по сравнению с короткими молекулами ПЭГ (750 Да и 120 Да) [35]. Отмечено, что повышенное содержание ПЭГ в системе предотвращает агрегацию липосом в крови, тогда как липосомы, полученные с более низким содержанием ПЭГ со временем агломерируются [37]. В работах [38,39] методами компьютерного моделирования исследован молекулярный механизм защитного 
действия ПЭГ. Было показано, что сравнительно малое число макромолекул ПЭГ способно образовывать защитный слой на поверхности липосом, предотвращающий опсонизацию белков. Предложены подходы для рассчета оптимальной концентрации ПЭГ на поверхности липосом для достижения их защитного эффекта при различной молекулярной массе.

В связи с тем, что ПЭГилированные липосомы способны направленно доставлять ЛВ, снижать общетоксическое действие и увеличивать время циркуляции в крови, их активно применяют для создания систем доставки противоопухолевых препаратов $[28,34,40]$. Показано, что при достаточно длительном периоде полувыведения ПЭГилированных липосом, небольшая их часть будет пассивно накапливаться в опухоли, избегая при этом здоровые ткани [41-43].

В настоящее время на стадии клинических испытаний находятся ПЭГилированный липосомальный цисплатин (SPI-077TM от Alza Corporation и LipoplatinTM от Regulon Inc.) и ПЭГилированный липосомальный полусинтетический аналог камптотецина (S-CKD602, Alza Corporation) [34,44-46]. Ведутся активно исследования в области разработки ПЭГилированных липосом с функциональными группами, такие как малеимиды, которые позволяют использовать их как различные лиганды для векторной доставки ЛВ [47,48], либо 
обеспечивать адгезию к слизистой ткани (мукоадгезия), что может использоваться для трансмукозальной доставки лекарств [49]. Наконец, проводятся исследования использовании ПЭГилированного липосомального рекомбинантного FVIII для лечения гемофилии А [50].

\section{ПЭГИЛИРОВАННЫЕ БЕЛКИ И ФЕРМЕНТЫ}

ПЭГилирование белков является клинически доказанным подходом к увеличению периода полувыведения и уменьшению иммуногенности протеиновой терапии [51-54]. Данный подход способствует увеличению молекулярной массы белков, маскирует их поверхность, улучшает фармакодинамику (механизм действия лекарства на организм) и фармакокинетику (химические превращения лекарства в организме) [55].

Получение ПЭГилированных конъюгатов белков обычно достигается посредством химической реакции между надлежащим образом активированным фрагментом ПЭГ и реакционноспособными группами белка, которые включают боковые цепи аминокислот (лизина, цистеина, гистидина, аргинина, аспарагиновой кислоты, глутаминовой кислоты, серина, треонина и тирозина) или N- концевую аминогруппу и С-концевую карбоновую кислоту [56]. Наиболее широко используемым типом макромолекул для белкового 
ПЭГилирования, является линейный мПЭГ, один конец макромолекул которого содержит метильные группы, а другой - гидроксильную группу, которая непосредственно участвует в связывании белка [22]. Применяется также разветвленная форма ПЭГ (мПЭГ2) в ПЭГилированных протеинах, у которой имеются две полимерные цепи, связанные одним активным фрагментом (рисунок 5). Конъюгаты ПЭГ с разветвленной формой, в результате большего экранирования поверхности, обладают длительным периодом полувыведения, в отличии от линейной [57-59] .

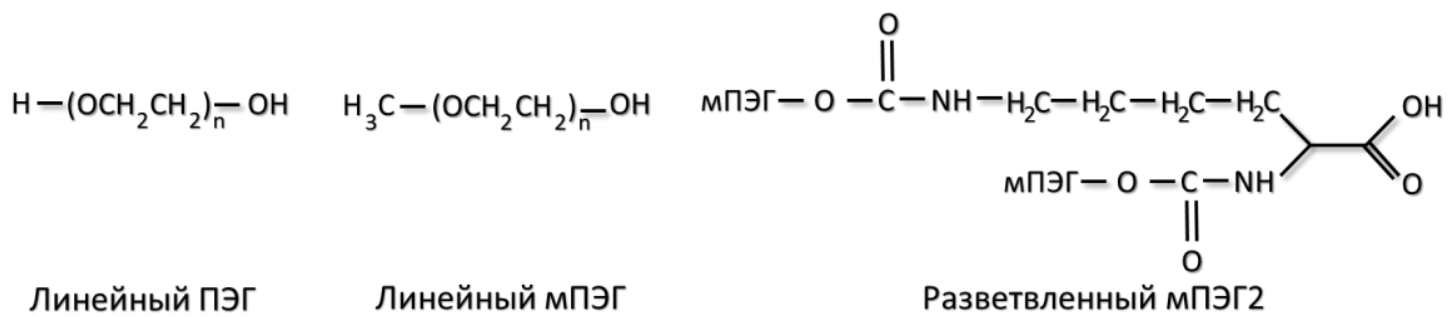

Рисунок 5. Структура различных молекул ПЭГ, используемая при получении ПЭГилированных белков: линейный ПЭГ, линейный монометокси-ПЭГ (мПЭГ) и разветвленный монометокси-ПЭГ (мПЭГ2).

Широкое использование ПЭГилированных конъюгатов и результаты поздних стадий клинических испытаний подтвердили важность химического состава и качества реагентов ПЭГ. Например, 
для ПЭГилированных белков первого поколения было характерно использование линейных макромолекул ПЭГ с низкой молекулярной массой, что приводило к возникновению побочных реакций, слабым связям с полипептидами и недостаточной селективностью при модификации [2,52].

Первоначально для получения активных макромолекул ПЭГ использовался хлорид циануровой кислоты (2-,4-,6-трихлортриазин), который реагировал с каталазой и бычьим сывороточным альбумином, в результате чего увеличивалось время циркуляции и снижалась иммуногенность, по сравнению с исходными белками $[24,60]$. Использовали также ПЭГ-дихлортриазин, который способен вступать в реакцию с нуклеофильными функциональными группами (тирозин, лизин, цистеин, гистидин и т.д.), с замещением одного из хлоридов и получением продукта с сохранением заряда на вторичном амине [61]. Реакционная способность оставшегося хлорида в итоге приводит к сшиванию белковых молекул, имеющих в своем составе нуклеофильные остатки, что отрицательно сказывалось на свойствах ПЭГилированных белков [2].

В основном методы получения производных ПЭГ в первом поколении были не способны генерировать чистые монофункциональные конъюгаты с высокой молекулярной массой, за 
исключением нескольких работ [62], поэтому ПЭГилирование второго поколения открыло новые возможности для модификации белков с образованием специфических мест связи.

Реагенты ПЭГ данного поколения являются N-концевыми или тиольными, которые демонстрируют избирательную селективность по отношению к лизину. Лизин является одной из наиболее распространенной аминокислотой и может составлять до 10\% от общей аминокислотной последовательности в белках.

Одним из первых представителей второго поколения является мПЭГ-пропиональдегид [63], полученный путем модификации N концевой аминогруппы [64]. Таким образом, полной селективности не наблюдалось, однако обширная гетерогенность, проявляющаяся в отношении модификации лизина, была значительно снижена [2]. Neulasta®, ПЭГилированный гранулоцитарный колониестимулирующий фактор (Г-КСФ), одобренный в 2002 году, был получен с помощью ковалентной конъюгации ПЭГ с N-концевым метионильным остатком [51]. Модификация N-концевого амина в основном происходит путем восстановительного аминирования $[2,64,65]$ и считается по праву способом образования специфических мест связи с белком [51,64,66-69]. 
Другим способом образования специфических связей с белком является присоединение молекул цистеина к белку. Благодаря присутствию тиольных групп в данной аминокислоте возможно образование ковалентной связи в присутствии других нуклеофилов, что минимизирует потерю биологической активности $[51,52,70]$. Более того, цистеин может быть добавлен к полипептидам именно в месте, где они необходимы с помощью генной инженерии [70,71]. Примером образования специфических мест связей с белком посредством цистеина является ПЭГилированный продукт CIMZIA® (UCB Pharma S.A., Бельгия), получивший одобрение в 2008 году (Таблица 1) $[34,51,72]$. 
Таблица 1. Поставляемые на рынок и одобренные FDA конъюгаты ПЭГилированных белков. Таблица составлена по данным, взятым из $[34,51]$.

\begin{tabular}{|c|c|c|c|c|c|}
\hline $\begin{array}{l}\text { Наименование } \\
\text { ПЭГилированного } \\
\text { продукта } \\
\text { (производитель) }\end{array}$ & $\begin{array}{l}\text { ПЭГилированный } \\
\text { конъюгат }\end{array}$ & $\begin{array}{l}\text { Место } \\
\text { связи ПЭГ } \\
\text { с } \\
\text { молекулой }\end{array}$ & $\begin{array}{l}\text { Молекулярная } \\
\text { масса } \\
\text { (кДа) }\end{array}$ & $\begin{array}{l}\text { Год } \\
\text { утверждения }\end{array}$ & Обоснование \\
\hline $\begin{array}{l}\text { Adagen }{ }^{\circledR} \\
\text { (Enzon Inc) }\end{array}$ & ПЭГадемаза & лизин & 5 & 1990 & $\begin{array}{l}\text { увеличение } \\
\text { периода } \\
\text { полувыведения }\end{array}$ \\
\hline $\begin{array}{l}\text { Oncaspar® } \\
(\text { Enzon Inc) }\end{array}$ & $\begin{array}{l}\text { ПЭГаспаргаза } \\
\text { (L-аспарагиназа) }\end{array}$ & лизин & 5 & 1994 & $\begin{array}{l}\text { увеличение } \\
\text { периода } \\
\text { полувыведения, } \\
\text { снижение } \\
\text { иммуногенности }\end{array}$ \\
\hline $\begin{array}{l}\text { PegIntron }{ }^{\circledR} \\
\text { (Schering- Plough } \\
\text { Corp) }\end{array}$ & $\begin{array}{l}\text { ПЭГинтерферон } \\
\text { (интерферон } \\
\text { альфа-2b) }\end{array}$ & $\begin{array}{l}\text { гистидин, } \\
\text { цистеин, } \\
\text { лизин, } \\
\text { серин, } \\
\text { тирозин, } \\
\text { гистидин }\end{array}$ & 12 & 2000-2001 & $\begin{array}{l}\text { увеличение } \\
\text { периода } \\
\text { полувыведения, } \\
\text { снижение } \\
\text { иммуногенности }\end{array}$ \\
\hline $\begin{array}{l}\text { Neulasta }{ }^{\circledR} \\
\text { (Amgen) }\end{array}$ & $\begin{array}{l}\text { ПЭГфилграстим } \\
\text { (ГМ-КСФ) }\end{array}$ & $\begin{array}{l}\text { N- } \\
\text { концевая } \\
\text { молекула } \\
\text { белка }\end{array}$ & 20 & $2002-2003$ & $\begin{array}{l}\text { увеличение } \\
\text { периода } \\
\text { полувыведения }\end{array}$ \\
\hline $\begin{array}{l}\text { Somavert }{ }^{\circledR} \\
\text { (Pfizer Inc) }\end{array}$ & $\begin{array}{l}\text { ПЭГвисомант } \\
\text { (генно- } \\
\text { инженерный } \\
\text { аналог } \\
\text { человеческого } \\
\text { гормона роста) }\end{array}$ & $\begin{array}{l}\text { лизин, } \\
\text { N- } \\
\text { концевая } \\
\text { молекула } \\
\text { белка }\end{array}$ & 5 & 2003 & $\begin{array}{l}\text { антагонист } \\
\text { рецептора } \\
\text { гормона роста, } \\
\text { увеличение } \\
\text { периода } \\
\text { полувыведения }\end{array}$ \\
\hline $\begin{array}{l}\text { Mircera }{ }^{\circledR} \\
\text { (Hoffman-La } \\
\text { Roche Ltd.) }\end{array}$ & $\begin{array}{l}\text { CERA } \\
\text { (эпоэтин-p) }\end{array}$ & лизин & 30 & 2007 & $\begin{array}{l}\text { увеличение } \\
\text { периода } \\
\text { полувыведения }\end{array}$ \\
\hline $\begin{array}{ll}\text { Cimzia }^{\circledR} & \\
\text { (UCB } & \text { Pharma } \\
\text { S.A.) } & \end{array}$ & $\begin{array}{l}\text { Цертолизумаб } \\
\text { ПЭГол } \\
\text { (anti-TNF-aFab') }\end{array}$ & $\begin{array}{l}\text { C- } \\
\text { концевая } \\
\text { молекула } \\
\text { белка }\end{array}$ & 40 & 2008 & $\begin{array}{l}\text { увеличение } \\
\text { периода } \\
\text { полувыведения, } \\
\text { снижение } \\
\text { иммуногенности }\end{array}$ \\
\hline $\begin{array}{l}\text { Krystexxa }{ }^{\circledR} \\
\text { (Savient } \\
\text { Pharmaceuticals) }\end{array}$ & $\begin{array}{l}\text { ПЭГлотиказа } \\
\text { (рекомбинантная } \\
\text { уриказа) }\end{array}$ & лизин & 10 & 2010 & $\begin{array}{l}\text { увеличение } \\
\text { периода } \\
\text { полувыведения }\end{array}$ \\
\hline
\end{tabular}

Еще одним примером селективного ПЭГилирования белков является окисление карбогидратных остатков или N-концевого серина 
или треонина [73]. На рисунке 6 приведены основные подходы, используемые при ПЭГилировании белков.

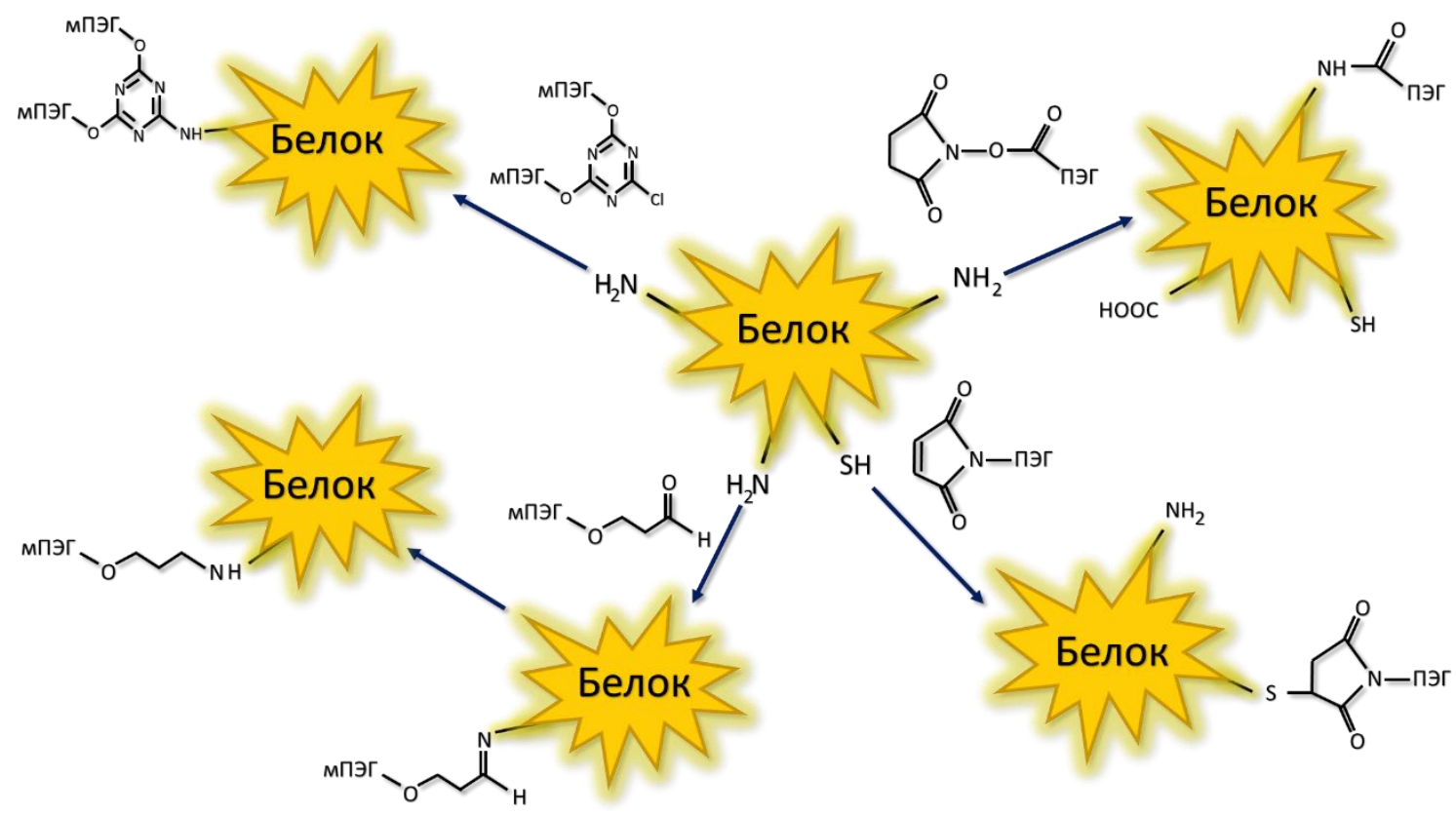

Рисунок 6. Функциональные группы, используемые для присоединения к концевым гидроксильным группам ПЭГ.

Сравнительные исследования белков с их ПЭГилированными аналогами в целом демонстрируют, что добавление ПЭГ существенно не меняет структуру белка, при его оценке с помощью спектроскопии ядерного магнитного резонанса (ЯМР), кругового дихроизма и УФспектрофотометрии [53,74-80]. Одним из ярких примеров является исследование двух конъюгатов, ПЭГилированных с помощью ПЭГ с молекулярной массой 5 кДа. В результате исследования, ЯМР-спектры ПЭГилированных конъюгатов не проявили структурного искажения 
из-за прикрепления макромолекул ПЭГ к белкам [77]. Сравнение 4 различных моноинсулиновых ПЭГилированных конъюгатов с помощью метода кругового дихроизма показало отсутствие заметных структурных различий при наличии ПЭГ [74,78].

Особенно важным при ПЭГилировании белков является проведение контрольных опытов, без присутствия ПЭГ, по результатам которых можно сделать вывод о достоверном различии эффектов и исключить влияние каких-либо условий реакций. Например, только неправильно свернутый белковый материал может быть в большей степени подвержен протеолизу или способствовать развитию иммуногенности [74].

Интересный подход к использованию свойств ПЭГилированных белков был предложен в работе Hayashi с соавторами [81], где лекарственные формы были получены в виде мукоадгезивных гелей на основе ИПК двух ПЭГилированных продуктов (папаина и соевого ингибитора трипсина) с ПАК. Образование этих гелей наблюдалось при $\mathrm{pH}$ 3,0 из-за формирования ИПК между звеньями ПЭГ и макромолекулами ПАК, стабилизированных водородными связями. При повышении рН среды до 7,4 имела место диссоциация ИПК, что приводило к высвобождению ПЭГилированных белков из гелей. Авторами рассмотрены перспективы использования таких систем для 
доставки ПЭГилированных белков в носовую полость, глаза и влагалище.

Использование ПЭГ для модификации белков также имеет и отрицательные стороны; из-за большой молекулярной массы в высоких дозах возможно его накопление в печени [82]. Недавние исследования на животных также показали образование антител против ПЭГ при введении ПЭГилированнных белков [51,83-85].

ПЭГИЛИРОВАННЫЕ ЧАСТИЦЫ ДЛЯ СИСТЕМНОГО ДЕЙСТВИЯ

В настоящее время накоплен опыт использования наночастиц, покрытых ПЭГ для системного действия с целью преодоления биологических барьеров и лечения различного рода заболеваний. Детально рассмотрены влияние физико-химических факторов, таких как молекулярная масса ПЭГ, поверхностная плотность, свойства ядра наночастиц, время повторного введения на эффективную доставку лекарств и генов [28,86-88]. Например, чтобы избежать взаимодействия с белками сыворотки крови и клетками мононуклеарной фагоцитарной системы (МФС), представляющей собой физиологическую защитную систему клеток, обладающих способностью поглощать и переваривать чужеродный материал, 
оболочка с ПЭГ должна обеспечивать достаточно толстый слой для экранирования поверхности наночастиц. Отмечено, что увеличение молекулярной массы ПЭГ, встроенного в ПЭГилированные мицеллы предотвращает агрегацию и адсорбцию компонентов крови, что приводит к увеличению времени их циркуляции in vivo [89]. Ключевую роль в конечном биораспределении играет размер частиц. Крупные частицы, которые не могут быть усвоены почками, имеющие гидродинамический радиус более 200 нм, обладают более высокой скоростью клиренса (процесс очищения биологических жидкостей или тканей организма), в отличии от частиц с меньшим радиусом, независимо от того, являются ли они ПЭГилированными или нет [90,91]. ПЭГилированные наночастицы с гидродинамическим радиусом менее 150 нм вызывают повышенное поглощение в костном мозге кроликов, в то время как частицы диаметром 250 нм, в основном, локализируются в селезенке и печени с незначительной долей поглощения костным мозгом [91,92]. Наиболее широко используемым методом определения поглощения частиц in vivo является применение радиоактивного ${ }^{14} \mathrm{C}$ или гистологические исследования инкапсулированного индия [91-96]. Изучение конечного уровня биораспределения и клиренса частиц in vitro наиболее часто проводится с помощью метода проточной цитометрии и измерения 
флуоресценции, связанной с клетками $[91,97,98]$. Показано, что на эффективность переноса системно вводимых векторов генов in vivo на основе ПЭГилированных полимеров влияет также форма наночастиц [99]. Стержнеобразная и червеобразная формы обладают более высокой экспрессией трансгена по сравнению со сферической, предполагая уменьшение поглощения удлиненных наночастиц клетками МФС. ПЭГилированные наночастицы используют для увеличения времени циркуляции частиц и накопления в опухоли, а также для снижения иммуногенности аденовирусов и увеличения времени циркуляции вирусных генных векторов, что дает предпосылки для использования ПЭГилированных покрытий в новых направлениях фармакотерапии [100,101].

\section{ПЭГИЛИРОВАННЫЕ ЧАСТИЦЫ, КАК НОСИТЕЛИ С УСИЛЕННОЙ ПРОНИЦАЕМОСТЬЮ}

Доставка лекарств непосредственно к месту локализации очага заболевания, избегая при этом системного действия, способна также значительно улучшить фармакотерапию. Однако, при местном применении лекарственных препаратов, существует ряд препятствий, такие как «биологические барьеры», ограничивающих их полноценное действие. Одним из таких барьеров являются слизистые оболочки, 
которые покрывают поверхность органов дыхания, мочевой, половой и пищеварительной систем, а также поверхности глаз. Они надежно защищают эпителий, обладая высокой адгезией к патогенам [102-105], частицам окружающей среды и системам доставки лекарств на основе частиц [102,106,107], способствуя их быстрому удалению. Таким образом, защитные свойства слизистых оболочек ограничивают возможности доставки ЛВ и генов через их поверхность. Проникновение частиц глубоко через слизистый барьер без ущерба его защитных свойств может способствовать улучшению профилактического и терапевтического лечения [102], что можно достичь посредством процесса ПЭГилирования. Для получения ПЭГилированных коллоидных частиц могут быть использованы те же принципы и химические реакции, что и для ПЭГилирования белков, ферментов и липосом.

Одними из первых исследований в области проникновения ПЭГилированных систем через слизистые оболочки были проведены на основе изучения диффузии наночастиц в образцах свежей цервиковагинальной слизи человека. В результате было показано, что наночастицы размером до 500 нм могут быстро диффундировать, если они плотно покрыты низкомолекулярным ПЭГ [106,108]. Позднее, на примере наночастиц, на основе сополимеров молочной и гликолевой 
кислот (ПМГК), было также подтверждено, что их проникновение через слизь обеспечивает улучшенную доставку в цервикальный канал, при этом использование ПЭГилированных покрытий увеличивает скорость диффузии [109]. Наночастицы с ПЭГилированным покрытием на основе плюроника F127 (триблок сополимера ПЭГполипропиленгликоль-ПЭГ) обеспечили значительное улучшение и более равномерное покрытие поверхности шейки матки и влагалища у мышей [28], что дает дополнительные преимущества при доставке лекарств. Сами по себе, плюроники способны образовывать мицеллярные структуры, с более гидрофобным ядром, состоящим из полипропиленгликоля, и гидрофильной ПЭГилированной опушкой. Многие лекарственные препараты, обладающие низкой растворимостью в воде, могут быть солюбилизированы в растворах плюроников и наличие ПЭГилированной поверхности в таких системах оказывает существенное влияние на проницаемость через биологические мембраны [110].

Положительные свойства ПЭГилированных наночастиц также были также обнаружены при доставке в слизистую оболочку носа [111]. Отмечено, что слизь с высокой степенью вязкости накапливается в пазухах носа у больных с хроническим риносинуситом. В этом случае терапия наночастицами должна обеспечить проникновение в 
слизистую, во избежание вымывания во время промывания и достичь нижележащих эпителиальных клеток. В этой связи было произведено измерение скорости диффузии наночастиц полистирола и их ПЭГилированных конъюгатов в свежей слизи пациентов с хроническим риносинуситом в обычной и полипозной форме. Исследование установило, что ПЭГилированные частицы размером до 200 нм способны легко проникать во все образцы слизи с обычной формой хронического риносинусита и почти половину образцов от пациентов с полипом носа.

Измерение скорости диффузии частиц применяли также для оценки проникающей способности через высоковязкую мокроту, которая препятствует эффективной доставке ЛВ на основе наночастиц и гена в легкие у пациентов с муковисцидозом - наследственным заболеванием, характеризующимся поражением желёз внешней секреции и тяжёлыми нарушениями функций органов дыхания [112]. Частицы диаметром до 200 нм, которые были покрыты ПЭГ с низкой молекулярной массой, перемещались через неразбавленную мокроту до 90 раз быстрее, чем частицы аналогичного размера без покрытия. С другой стороны, транспорт частиц размером 500 нм с ПЭГ и без его покрытия был сильно затруднителен. Используя результаты определения скорости переноса частиц различных размеров в 
сочетании с 3D-масштабированием препятствий, было уставлено, что размер пор составляет примерно $140 \pm 50$ нм. Таким образом, наночастицы диаметром до 200 нм способны проходить данный барьер, при этом ПЭГилированные покрытия увеличивают скорость доставки ЛВ.

Преодоление естественных защитных функций глаза также является актуальной проблемой для местной доставки лекарств. Исследование барьерных свойств роговицы глаза было произведено с помощью флуоресцентно-меченных частиц, помещенных на поверхность коровьей роговицы [113]. Результаты эксперимента показали, что основным барьером для проникновения частиц является эпителий роговицы. Предварительная ее обработка $\beta$-ЦД обеспечивает более высокую проницаемость низкомолекулярных соединений, таких как флуоресцеин натрия, но не улучшает проникновение наночастиц и более крупных молекул. Воздействие ПЭГилированных органосиликатных наночастиц с молекулярной массой ПЭГ 750 Да на поверхность глаза продемонстрировало их способность к мукоадгезии. Однако, использование ПЭГ с более высокой молекулярной массой (5 кДа) позволяет наночастицам проникать через роговицу после удаления эпителиального слоя [113]. Ранеe Irmukhametova c соавторами [114] было проведено сравнительное исследование 
мукоадгезивных свойств и удерживания тиолированных органосиликатных наночастиц и их ПЭГилированного аналога на слизистой поверхности роговицы глаз коров in vitro. Установлено, что тиолированные частицы обладают высокой мукоадгезивной способностью из-за образования ковалентных связей (-S-S- мостиков) с остатками цистеина, присутствующими в муцине. ПЭГилированные наночастицы показали отсутствие адгезии к поверхности слизистой оболочки глаз (Рисунок 7).
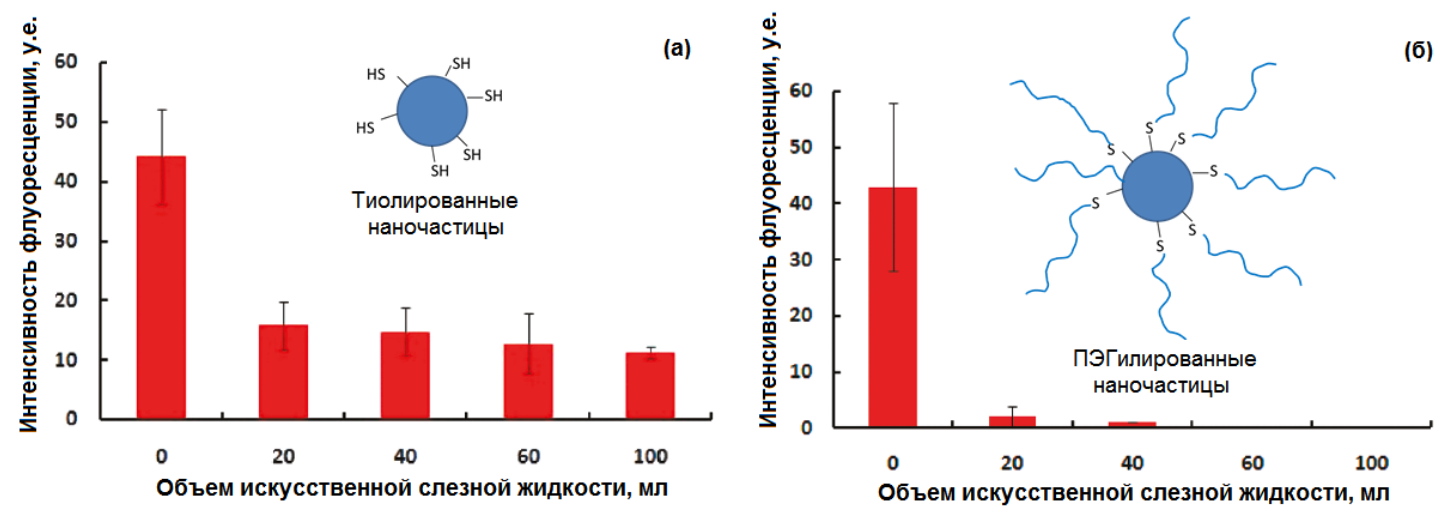

Рисунок 7. Удерживание тиолированных органосиликатных наночастиц (а) и их ПЭГилированного аналога (б) на поверхности роговицы глаз коровы в потоке искусственной слезной жидкости в экспериментах in vitro. Перепечатано из [114] с разрешения American Chemical Society. 
В работе [115] исследовано интравитреальное (внутриглазное) введение наночастиц полистирола размером до 510 нм, которое показало быстрое проникновение в стекловидное тело при покрытии их ПЭГ, в то время, как движение наночастиц диаметром 1190 нм было сильно ограничено вне зависимости от химического состава поверхности.

Потенциальные преимущества ПЭГилированных частиц также были показаны на здоровой и воспаленной слизистой оболочке кишечника. Нано- и микрочастицы ПМГК, и эти же частицы, покрытые хитозаном показали низкое проникновение в образцах здоровых тканей. ПЭГилированные наночастицы ПМГК продемонстрировали высокую проникающую способность через здоровую $(2,3 \%)$ и воспаленную слизистую оболочку $(5,3 \%)$. Примечательно, что ПЭГилированные микрочастицы показали повышенную проницаемость в воспаленной слизистой кишечника $(3,3 \%)$ по сравнению со здоровой $(4,1 \%)$ [116].

ПЭГИЛИРОВАННЫЕ ПОЛИЭЛЕКТРОЛИТЫ И КОМПЛЕКСЫ ФАРМАЦЕВТИЧЕСКОГО НАЗНАЧЕНИЯ

Некоторые полимеры, применяемые в различных фармацевтических технологиях, при их ПЭГилировании приобретают 
ряд ценных свойств, не характерных для исходных материалов. Так, в литературе имеются многочисленные сведения о ПЭГилированных производных хитозана, катионного полисахарида, имеющего ряд уникальных физико-химических и биофармацевтических свойств. ПЭГилирование хитозана может быть осуществлено путем нескольких различных подходов, например, посредством его реакции с ПЭГ содержащими альдегидными, карбоксильными, карбонатными, иодидными, эпоксидными, акрилатными, $\mathrm{N}$ гидроксисукцинимидными и сульфонатными группами [117].

Присоединение ПЭГ к хитозану в этом случае происходит, как правило, с участием его аминогрупп. В литературе также имеются сведения о ПЭГилировании хитозана через гидроксильные группы [117]. Как правило, ПЭГилирование хитозана приводит к существенному изменению характера его растворимости в воде. Так, исходный хитозан обычно теряет свою растворимость в воде при $\mathrm{pH}>6,5$ из-за депротонирования аминогрупп и потери положительного заряда на его макромолекулах [118]. ПЭГилированный хитозан, при достаточной степени замещения и молекулярной массе ПЭГ не проявляет рН-зависимую растворимость и остается в растворе даже при высоких значениях рН (Рисунок 8). 


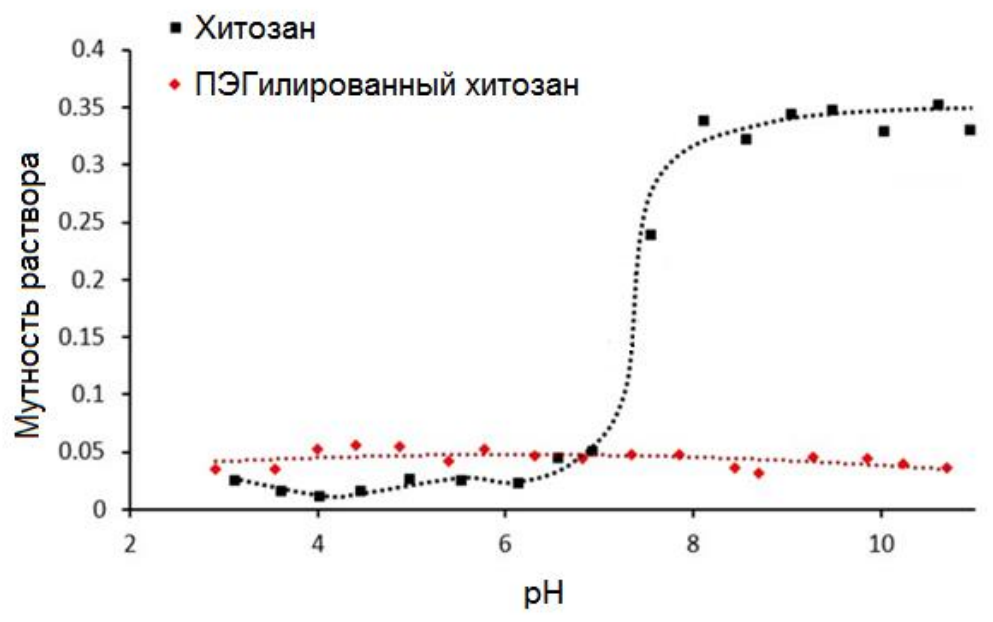

Рисунок 8. Мутность раствора хитозана и его ПЭГилированного производного в зависимости от рН. Мутность была измерена при 400 нм. Перепечатано из [119] с разрешения автора.

Несмотря на то, что хитозан является биосовместимым материалом, ПЭГилирование улучшает его токсикологические характеристики и снижает цитотоксичность по отношению к различным клеткам [117].

Сведения о фармацевтических применениях ПЭГилированного хитозана включают использование данных производных для получения наночастиц в качестве носителей ЛВ. Наличие в ПЭГилированном хитозане многочисленных остаточных аминогрупп сохраняет его полиэлектролитные свойства и позволяет получать различные комплексы с анионными фармакологически-активными 
полисахаридами, пептидами, белками и олигонуклеотидами. Например, Вае с соавторами [120] сообщалось о получении наноносителей на основе интерполиэлектролитных комплексов (ИПЭК) ПЭГилированного хитозана и анионного полисахарида гепарина, которые вызывали процесс программируемой клеточной гибели (апоптоз) раковых клеток В16F100 in vitro. Данные частицы ИПЭК имели сферическую форму и размеры порядка 200 нм. Они сохраняли отличную коллоидную стабильность в плазме крови благодаря стерической стабилизации, обеспечиваемой короной ПЭГ. В другой работе, Yang с соавторами [121] были получены наноносители противоракового ЛВ (метотрексат), путем его комплексообразования с ПЭГилированным хитозаном. Данные носители представляли собой наночастицы до 300 нм, в которых содержание метотрексата составляло от 21 до 95 \% в зависимости от степени ПЭГилирования хитозана и соотношения полиэлектролит:ЛВ.

Сообщалось также о ПЭГилированных катионных производных хитозана, поли(L-лизина) и полиэтиленимина в качестве носителей плазмидных ДНК, коротких интерферирующих PHК (siRNA) и олигонуклеотидов [122-124]. ПЭГилирование, при этом, может способствовать улучшению способности полимеров к трансфекции (процесс введения нуклеиновой кислоты в клетки), увеличению 
времени циркуляции и стабильности к хранению поликомплексов с носителями генетической информации.

В литературе также имеются сведения о ПЭГилировании анионных полимеров фармацевтического назначения. Так, например, Alibolandi c соавторами [125] были получены ПЭГилированные производные ацетилированной карбоксиметилцеллюлозы, к которым также был химически присоединен противораковый препарат 7-этил10-гидроксикамптотецин. Полученные конъюгаты образовывали наночастицы, которые были дополнительно модифицированы присоединением аптамеров РНК, позволяющим осуществлять узнавание специфических рецепторов CD133 (проминин-1), присутствующих на поверхности раковых клеток. Данные носители показали повышенное поглощение и цитотоксичность по отношению к раковым клеткам НТ29 по сравнению с клетками СНО, у которых нет рецепторов CD133.

Shin c соавторами [126] были получены ПЭГилированные производные гиалуроновой кислоты, которые были использованы в качестве носителей овальбумина как модельного антигена. В качестве связующего звена между макромолекулами гиалуроновой кислоты и ПЭГ были использованы группы, подвергающиеся ферментативному расщеплению под действием матричной металлопротеазы 9 (MМР9). 
Это придавало полученному конъюгату свойства, чувствительные к ММР9, что приводило к отщеплению короны ПЭГ при попадании в орган-мишень и эффективному поглощению такой системы раковыми клетками ТС-1.

Таким образом, ПЭГилирование некоторых полиэлектролитов позволяет получать полимеры с уникальными свойствами, существенно отличающимися от исходных материалов. ПЭГилированные полиэлектролиты, как правило, сохраняют свои полиэлектролитные свойства и способны к образованию комплексов с противоположно-заряженными полимерами, биополимерами и малыми молекулами. Такие системы могут быть использованы при создании нано-носителей лекарственных препаратов.

\section{ПЭГИЛИРОВАННЫЕ ЛЕКАРСТВЕННЫЕ ПРЕПАРАТЫ}

Альтернативным способом использования процесса ПЭГилирования является конъюгация ПЭГ с ЛВ, хорошо известным благодаря сниженной иммуногенности, токсичности и низкому усвоению макрофагами и, как следствие, длительному кровообращению [127-129]. В частности, данный процесс был использован для солюбилизации и доставки противоопухолевого лекарственного препарата - паклитаксела (таксола). В результате были 
получены водорастворимые сложные эфиры 2-таксола полиэтиленгликоля и показано, что они действуют в качестве пролекарств в экспериментах in vitro. Было установлено, что присоединение ПЭГ к лекарствам или пролекарствам требует использования полимера с молекулярной массой $\geq 30$ кДа для предотвращения быстрого выведения ПЭГилированных соединений [128]. Другим примером является получение пролекарства с использованием противопухолевого препарата камптотецина (пегамотекан) [130]. Камптотецин конъюгировали с ПЭГ (40 кДа) посредством связи аланинового эфира в присутствии диизопропилкарбодиимида. Активной частью молекулы камптотецина, ответственной за конформационные изменения между лактоном и карбоксилатными формами, является гидроксильная группа в 20-м положении. В результате синтеза данная группа блокируется аланиновой связью, которая стабилизирует молекулу в активную конформацию лактона [131]. Пегамотекан прошел I фазу клинических исследований, однако был исключен из испытаний во время изучения во II фазе из-за недостаточной эффективности $[132,133]$.

Возможным ограничением использования ПЭГ в качестве носителя ЛВ является наличие всего двух реакционноспособных групп 
на полимерную цепь, что ограничивает возможность высокой загрузки лекарства. В качестве решения данной проблемы была предложена дендритная структура концевой цепи ПЭГ. На основе данного направления компания Enzon Pharmaceuticals, Inc. разработала конъюгат SN38, представляющий собой активный метаболит камптотецина с использованием ПЭГ (40 кДа), имеющий в своем составе четыре концевых группы [131,134]

Другим способом получения ПЭГилированных пролекарств является использование ангидридных связей между молекулами лекарства и ПЭГ, разработанным Lele и Hoffman [127]. Однако, при этом положительный результат можно ожидать у ЛВ, имеющих в своем составе по меньшей мере одну реакционноспособную карбоксильную группу. Данный способ был разработан для доставки ПЭГилированных лекарств в качестве мукоадгезивных систем, поскольку муцин на слизистых оболочках обладает выраженным свойством текучести и наносимый препарат подвержен быстрой утилизации с поверхности слизистой оболочки, независимо от мукоадгезионной силы $[127,135]$. В качестве модельного ЛВ был выбран индометацин, имеющий в своем составе карбоксильную группу и используемый для доставки лекарств в глаза, как нестероидный противовоспалительный препарат (Рисунок 9). 


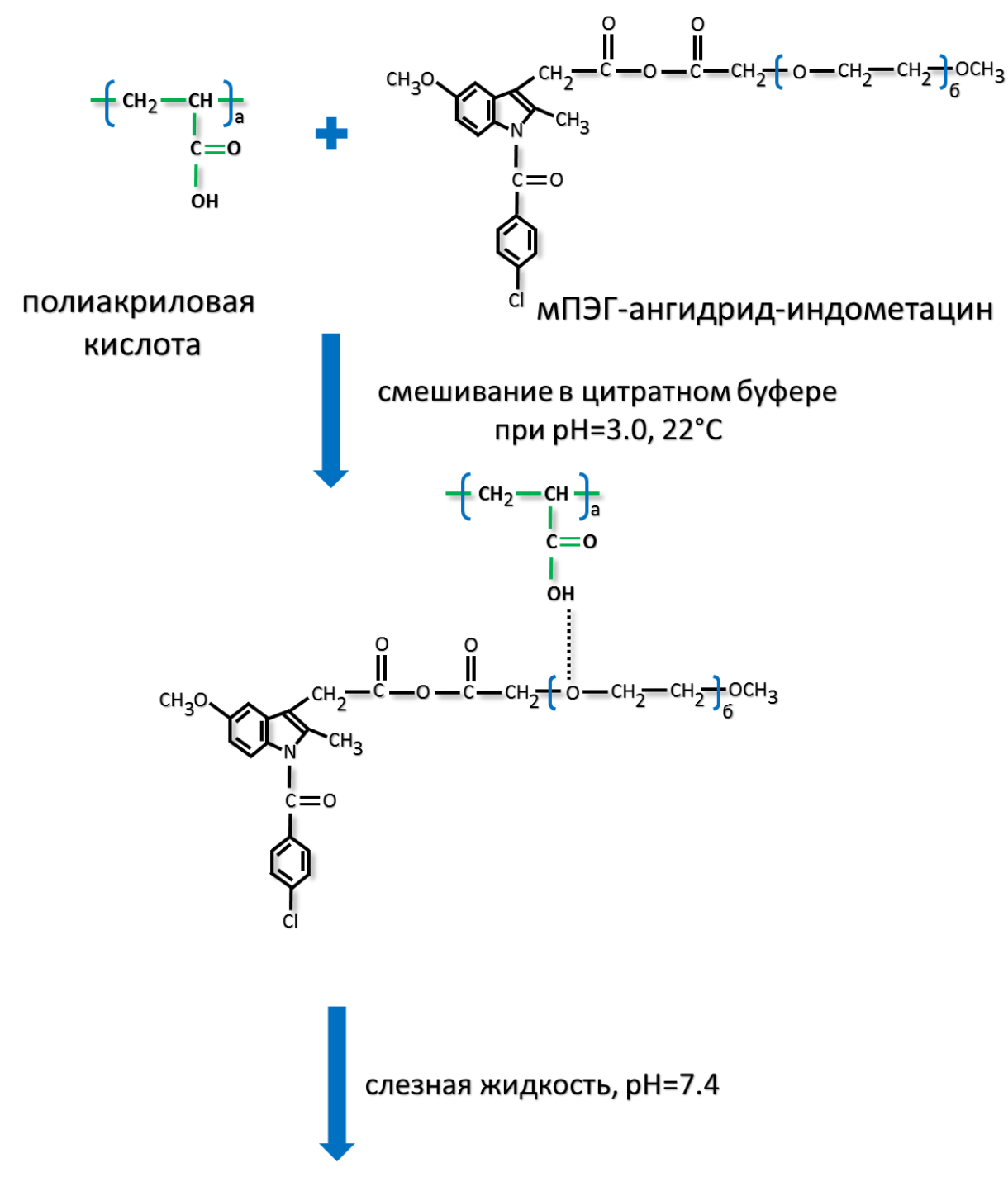

полиакриловая кислота + свободный мПЭГ-СООН + свободный индометацин

Рисунок 9. Структура комплексов, образованных конъюгатом мПЭГ-ангидрид-индометацин и ПАК, и их диссоциация в слезной жидкости. Перепечатано из [127] с разрешением Elsevier.

Впоследствии, на основе ПЭГилированного индометацина были получены комплексы с ПАК, предназначенные для диссоциации во время набухания состава, при контакте с поверхностями слизистых 
оболочек (pH 7,4). В результате полученные комплексы при достижении поставленных условий высвобождают ПЭГ-индометацин, который далее гидролизуется с высвобождением свободного ЛВ и ПЭГ [127].

Накоплен также опыт образования систем «неразлагаемый полимер-ЛВ», в частности, был синтезирован и охарактеризован in vitro - ПЭГилированный галоперидол для селективной доставки в центральную или периферическую нервную систему, модулируя дофаминергическую систему, представляющую собой совокупность взаимосвязанных нейронов, секретирующих в качестве трансмиттера дофамин. Полученный конъюгат продемонстрировал превосходную стабильность при испытании in vitro, при этом были проведены исследования связывания радиолиганда, которые выявили, что способность связываться с дофаминовым D2-рецептором $\mathrm{y}$ ПЭГилированного галоперидола выражена в меньшей степени по сравнению со свободным лигандом. Теоретическое моделирование показало, что конъюгат может резко ограничить прохождение галоперидола через гематоэнцефалический барьер (полупроницаемый барьер между кровью и нервной тканью). Совокупность данных результатов демонстрирует необходимость проведения исследований ПЭГилированного галоперидола in vivo, в контексте разработки 
системы, способной селективно (периферически или центрально) модулировать дофаминергическую систему [136].

Активные исследования в области ПЭГилированния лекарств нашли отражение в получении первого перорального ПЭГилированного опиоидно антагониста - ПЭГ- налоксегола (Movantik ${ }^{\mathrm{TM}}$ ), используемого для лечения опиоид-индуцированной дисфункции кишечника, сохраняя при этом центральный анальгетический эффект опиоидов. В результате, данный конъюгат прошел все клинические испытания и был одобрен FDA [134,136,137].

Таким образом, ПЭГилирование может эффективно увеличить растворимость нерастворимых в воде соединений, снизить токсичность и создать благоприятный фармакокинетический профиль [134]. При этом возникающие трудности в процессе разработки ПЭГилированных лекарств незначительны с недавними успешными данными о препаратах, введенных в клинические испытания, которые открывают новые перспективы в фармакотерапии различных заболеваний.

\section{ВЫВОДЫ}

Полиэтиленгликоль является водорастворимым полимером, обладающим широким набором уникальных физико-химических и биологических свойств, что обуславливает его применение в 
различных областях фармацевтики и медицины. Основываясь на многолетнем успехе ПЭГилирования белков, пептидов, липосом и наночастиц для системного действия и преодоления различных внеклеточных барьеров, его можно считать одним из высокоэффективных подходов для улучшения доставки лекарственных веществ и генов. Положительные свойства макромолекул ПЭГ, несомненно, будут играть решающую роль при разработке новых лекарственных препаратов в будущем. 


\section{СПИСОК ЛИТЕРАТУРЫ}

1. Herzberger J., Niederer K., Pohlit H., Seiwert J., Worm M., Wurm F.R., Frey H. // Chem. Rev. 2016. V. 116. № 4. P. 2170-2243.

2. Roberts M. J., Bentley M. D., Harris J. M. // Adv. Drug Deliv. Rev. 2002. V. 54. № 4. P. 459-476.

3. Кабанов B.A. Энциклопедия полимеров. Том 2. Изд.: Советская энциклопедия, 1974. С. 427-432.

4. Кнуняни И.Л. Химия: Большой Энциклопедический словарь. Москва: Большая Российская Энциклопедия, 1988.

5. Pielichowski K., Flejtuch K. // Polym. Adv. Technol. 2002. V. 13. P. 690-696.

6. Majumdar R., Alexander K.S., Riga A.T. // Pharmazie. 2010. V. 65. № 5. P. 342-346.

7. Бектуров Е.А., Бакауова 3.Х. Синтетические водорастворимые полимеры в растворах. Алма-Ата: Наука, 1981.

8. Кабанов В.А., Паписов И.М. // Высокомолек.соед.А. 1979. Т. 21. № 2. C. 243.

9. Bekturov E.A., Bimendina L.A. // Adv.Polym.Sci. 1981. V. 41. P. 99 147. 
10. Tsuchida E., Abe K. // Adv. Polym. Sci. 1982. V. 45. P. 1.

11. Кеменова В.А., Мустафин Р.И., Алексеев К.В., Скородинская А.М., Зезин А.Б., Тенечова А.И., Кабанов В.А. // Фармация. 1991. T. 60. № 3. C. 67-72.

12. Hydrogen-Bonded Interpolymer Complexes: Formation, Structure and Applications. Hackensack / Ed. Khutoryanskiy V. V., Staikos G. World Scientific Publishing Co. Pte. Ltd., 2009.

13. Бектуров Е.А., Хамзамулина Р.Э., Бакауова 3.Х., Кудайбергенов С.Е., Джумадилов Т.К., Чердабаев А.Ш., Акаубеков М.А. Молекулярные комплексы полимеров. Алма-Ата: Наука, 1988. С. 176.

14. Аксенова Н.И., Кеменова В.А., Харенко А.В., Зезин А.Б., Бравова Г.Б., Кабанов В.А. // Высокомолек. Соед. Сер.А. 1998. Т. 40, № 3. C. 403-409.

15. Harada A., Li J., Kamachi M. // Macromolecules. 1993. V. 26. № 21. P. 5698-5703.

16. Irmukhametova G.S., Fraser B.J., Keddie J.L., Mun G.A., Khutoryanskiy V. V. // Langmuir. 2012. V. 28. № 1. P. 299-306.

17. Serres-Gómez M., González-Gaitano G., Kaldybekov D.B., Mansfield E.D.H., Khutoryanskiy V. V., Isasi J.R., Dreiss C.A. // 
Langmuir. 2018. V. 34. № 36. P. 10591-10602.

18. Geckil H., Xu F., Zhang X., Moon S., Demirci U. // Nanomedicine. 2010. V. 5. № 3. P. 469-484.

19. Wilems T.S., Lu X., Kurosu Y.E., Khan Z., Lim H.J., Smith Callahan L.A. // J. Biomed. Mater. Res. Part A. 2017. V. 105. № 11. P. 30593068.

20. Akiyama Y., Osuka H., Nagasaki Y., Kato M., Kataoka K. // Bioconj. Chem. 2000. V. 11. 947-950.

21. Harris J.M., Kozlowski A. Pat. US5672662A. 1997.

22. Никитин И.Г., Байкова И.Е., Гогова Л.М. // Лечебное дело. 2005. №4. C. 18-24.

23. Working P.K., Newman M.S., Johnson J., Cornacoff J.B. // ACS Symposium Series; ACS Publications: American, 1997. V. 680. P. $45-57$.

24. Abuchowski A., McCoy J.R., Palczuk N.C., van Es T., Davis F.F. // J. Biol. Chem. 1977. V. 252. № 11. P. 3582-3586.

25. Weissig V., Pettinger T.K., Murdock N. // Int. J. Nanomedicine. 2014. V. 9. P. 4357-4373.

26. Arturson P., Laakso T., Edman P. // J. Pharm. Sci. 1983. V. 72. № 12. 
P. $1415-1420$.

27. Tan J.S., Butterfield D.E., Voycheck C.L., Caldwell K.D., Li J.T. // Biomaterials. 1993. V. 14. № 11. P. 823-833.

28. Suk J.S., Xu Q., Kim N., Hanes J., Ensign L.M., // Adv. Drug Deliv. Rev. 2016. V. 99. P. 28-51.

29. Raikov A.O., Hashem A., Baryshnikova M.A. // Russ. J. Biother. 2016. V. 15. № 2. P. 90-96.

30. Blume G., Cevc G. // Biochim. Biophys. Acta. 1993. V. 1146. № 2. P. $157-168$.

31. Vert M., Domurado D. // J. Biomater. Sci. Polym. Ed. 2000. V. 11. № 12. P. $1307-1317$.

32. Immordino M.L., Dosio F., Cattel L. // Int. J. Nanomedicine. 2006. V. 1. № 3. P. 297-315.

33. Cattel L., Ceruti M., Dosio F. // J. Chemother. 2004. V. 16. Sup. 4. P. 94-97.

34. Milla P., Dosio F., Cattel L. // Curr. Drug Metab. 2012. V. 13. № 1. P. 105-119.

35. Allen T.M., Hansen C., Martin F., Redemann C.,Yau-Young A. // BBA - Biomembr. 1991. V. 1066. № 1. P. 29-36. 
36. Allen C., Dos Santos N., Gallagher R., Chiu G.N.C., Shu Y., Li W.M., Johnstone S.A., Janoff A.S., Mayer L.D., Webb M.S.,Bally M.B. // Biosci. Rep. 2002. V. 22. № 2. P. 225-250.

37. Braeckmans K., Buyens K., Bouquet W., Vervaet C., Joye P., De Vos F., Plawinski L., Doeuvre L., Angles-Cano E., Sanders N.N., Demeester J., De Smedt S.C. // Nano Lett. 2010. V. 10. № 11. P. $4435-4442$.

38. Torchilin V.P., Omelyanenko V.G., Papisov M.I., Bogdanov A.A., Trubetskoy V.S., Herron J.N., Gentry C.A. // Biochim. Biophys. Acta. 1994. V. 1195. № 1. P. 11-20.

39. Torchilin V.P., Papisov M.I. // J. Liposome Res. 1994. V.4. №1. 725739.

40. Deshpande P.P., Biswas S., Torchilin V.P. // Nanomedicine (Lond). 2013. V. 8. №9. P. 1509-1528.

41. Allen T.M., Hansen C., Rutledge J. // Biochim. Biophys. Acta. 1989. V. 981. № 1. P. 27-35.

42. Allen T.M., Chonn A. // FEBS Lett. 1987. V. 223. № 1. P. 42-46.

43. Klibanov A.L., Maruyama K., Torchilin V.P., Huang L. // FEBS Lett. 1990. V. 268. № 1. P. 235-237. 
44. Seetharamu N., Kim E., Hochster H., Martin F., Muggia F. // Anticancer Res. 2010. V. 30. № 2. P. 541-545.

45. Boulikas T. // Expert Opin. Investig. Drugs. 2009. V. 18. № 8. P. $1197-1218$.

46. Zamboni W.C., Ramalingam S., Friedland D.M., Edwards R.P., Stoller R.G., Strychor S., Maruca L., Zamboni B.A., Belani C.P., Ramanathan R.K. // Clin. Cancer Res. 2009. V. 15. № 4. P. 14661472.

47. Li T., Takeoka S. // Int. J. Nanomedicine. 2013. V.8. P. 3855-3866.

48. Golkar N., Tamaddon A.M., Samani S.M. // J. Liposome Res. 2015. V.26. №2. P. 113-125.

49. Kaldybekov D.B., Tonglairoum P., Opanasopit P., Khutoryanskiy V. V. // Eur. J. Pharm. Sci. 2018. V. 111. P. 83-90.

50. Di Minno G., Cerbone A.M., Coppola A., Cimino E., Di Capua M., Pamparana F., Tufano A., Di Minno M.N. // Haemophilia. 2010. V. 16. Suppl.1. P. 2-6.

51. Ginn C., Khalili H., Lever R., Brocchini S. // Future Med. Chem. 2014. V. 6. № 16. P. 1829-1846.

52. Kolate A., Baradia D., Patil S., Vhora I., Kore G., Misra A. // J. 
Control. Release. 2014. V. 192. P. 67-81.

53. Pasut G., Veronese F.M. // J. Control. Release. 2012. V. 161. № 2. P. $461-472$.

54. Bailon P., Won C.Y. // Expert Opin. Drug Deliv. 2009. V. 6. № 1. P. $1-16$.

55. Veronese F.M. // Biomaterials. 2001. V. 22. № 5. P. 405-417.

56. Roberts M.J., Harris J.M. // J. Pharm. Sci. 1998. V. 87. № 11. P. $1440-1445$.

57. Fee C.J. // Biotechnol. Bioeng. 2007. V. 98. № 4. P. 725-731.

58. Kusterle M., Jevševar S., Porekar V.G. // Acta Chim. Slov. 2008. V. 55. № 3. Р. 594-601.

59. Veronese F.M., Caliceti P., Schiavon O. // J. Bioact. Compat. Polym. 1997. V. 12. № 3. P. 196-207.

60. Abuchowski A., van Es T., Palczuk N.C., Davis F.F. // J. Biol. Chem. 1977. V. 252. № 11. P. 3578-3581.

61. Zalipsky S., Lee C. // In Harris J.M., Zalipsky S. (eds) Poly(Ethylene Glycol) Chemistry. Topics in Applied Chemistry. Springer, Boston, MA. P. 347-370.

62. Bentley M.D., Harris J.M., Kozlowski A. Pat. US6448369B1 USA. 
1999.

63. Harris J.M., Herati R.M. Pat. US5252714A USA. 1993.

64. Kinstler O.B., Brems D.N., Lauren S.L., Paige A.G., Hamburger J.B., Treuheit M.J. // Pharm. Res. 1996. V. 13. № 7. P. 996-1002.

65. Kinstler O., Molineux G., Treuheit M., Ladd D., Gegg C. // Adv. Drug Deliv. Rev. 2002. V. 54. № 4. P. 477-485.

66. Bell S.J., Fam C.M., Chlipala E.A., Carlson S.J., Lee J.I., Rosendahl M.S., Doherty D.H., Cox G.N. // Bioconjug. Chem. 2008. V. 19. № 1. P. 299-305.

67. Wang J., Hu T., Liu Y., Zhang G., Ma G., Su Z. // Anal. Biochem. 2011. V. 412. № 1. P. 114-116.

68. Lee H., Jang I.H., Ryu S.H., Park T.G. // Pharm. Res. 2003. V. 20. № 5. P. $818-825$.

69. Tong Y., Zhong K., Tian H., Gao X., Xu X., Yin X., Yao W. // Int. J. Biol. Macromol. 2010. V. 46. № 3. P. 331-336.

70. Goodson R.J., Katre N. V // Biotechnology (N.Y). 1990. V. 8. № 4. P. 343-346.

71. Harris J.M., Chess R.B. // Nat. Rev. Drug Discov. 2003. V. 2. № 3. P. $214-221$. 
72. EMEA. Cimzia 'assesment report'.

www.ema.europa.eu/docs/en_GB/document_library/EPAR__Public_assessment_report/human/001037/ WC500069735.pdf.

73. Zalipsky, S. Menon-Rudolph, in: J.M. Harris, S. Zalipsky (Eds.), Poly(ethylene glycol) Chemistry and Biological Applications, ACS Books, Washington, DC, 1997, P. 318-340

74. Turecek P.L., Bossard M.J., Schoetens F., Ivens I.A. // J. Pharm. Sci. 2016. V. 105. № 2. P. 460-475.

75. Banci L., Bertini I., Scolaro L.M., Caliceti P., Schiavon O., Veronese F.M. // J. Inorg. Biochem. 1990. V. 39. № 2. P. 149-159.

76. Veronese F.M., Sartore L., Schiavon O., Caliceti P. // Ann. N. Y. Acad. Sci. 1990. V. 613. P. 468-474.

77. Digilio G., Barbero L., Bracco C., Corpillo D., Esposito P., Piquet G., Traversa S., Aime S. // J. Am. Chem. Soc. 2003. V. 125. № 12. P. 3458-3470.

78. Hinds K.D., Kim S.W. // Adv. Drug Deliv. Rev. 2002. V. 54. № 4. P. $505-530$.

79. Meng F., Manjula B.N., Smith P.K., Acharya S.A. // Bioconjug. Chem. 2008. V. 19. № 7. P. 1352-1360. 
80. Veronese F.M., Mero A., Caboi F., Sergi M., Marongiu C., Pasut G. // Bioconjug. Chem. 2007. V. 18. № 6. P. 1824-1830.

81. Hayashi Y., Harris J.M., Hoffman A.S. // React. Funct. Polym. 2007. V. 67. № 11. P. 1330-1337.

82. Yamaoka T., Tabata Y., Ikada Y. // J. Pharm. Sci. 1994. V. 83. № 4. P. $601-606$.

83. Garay R.P., Labaune J.R. // Open Conf. Proc. J. 2011. V. 2. P. 104107.

84. Armstrong J.K., Hempel G., Koling S., Chan L.S., Fisher T., Meiselman H.J., Garratty G. // Cancer. 2007. V. 110. № 1. P. 103111.

85. Ganson N.J., Kelly S.J., Scarlett E., Sundy J.S., Hershfield M.S. // Arthritis Res. Ther. 2006. V. 8. № 1. P. R12.

86. Yoo J.W., Chambers E., Mitragotri S. // Curr. Pharm. Des. 2010. V. 16. № 21. P. 2298-2307.

87. Nance E., Timbie K., Miller G.W., Song J., Louttit C., Klibanov A.L., Shih T.Y., Swaminathan G., Tamargo R.J., Woodworth G.F., Hanes J., Price R.J. // J. Control. Release. 2014. V. 189. P. 123-132.

88. GrefR., Lück M., Quellec P, Marchand M., Dellacherie E., Harnisch 
S., Blunk T., Müller R.H. // Colloids Surf. B. Biointerfaces. 2000. V. 18, № 3-4. P. 301-313.

89. Miteva M., Kirkbride K.C., Kilchrist K. V., Werfel T.A., Li H., Nelson C.E., Gupta M.K., Giorgio T.D., Duvall C.L. // Biomaterials. 2015. V. 38. P. 97-107.

90. Moghimi S.M., Hedeman H., Muir I.S., Illum L., Davis S.S. // Biochim. Biophys. Acta. 1993. V. 1157. № 3. P. 233-240.

91. Owens D.E., Peppas N.A. // Int. J. Pharm. 2006. V. 307. № 1. P. 93102.

92. Porter C.J., Moghimi S.M., Illum L., Davis S.S. // FEBS Lett. 1992. V. 305. № 1. P. 62-66.

93. Leu D., Manthey B., Kreuter J., Speiser P., Delucax P.P. // J. Pharm. Sci. 1984. V. 73. № 10. P. 1433-1437.

94. Tröster S.D., Wallis K.H., Müller R.H., Kreuter J. // J. Control. Release. 1992. V. 20. № 3. P. 247-260.

95. Gref R., Minamitake Y., Peracchia M.T., Trubetskoy V., Torchilin V., Langer R. // Science. 1994. V. 263. № 5153. P. 1600-1603.

96. Bazile D., Prud'homme C., Bassoullet M.T., Marlard M., Spenlehauer G., Veillard M. // J. Pharm. Sci. 1995. V. 84. № 4. P. 
493-498.

97. De Jaeghere F., Allemann E., Feijen J., Kissel T., Doelker E., Gurny R. // J. Drug Target. 2000. V. 8. № 3. P. 143-153.

98. Jaulin N., Appel M., Passirani C., Barratt G., Labarre D. // J. Drug Target. 2000. V. 8. № 3. P. 165-172.

99. Jiang X., Qu W., Pan D., Ren Y., Williford J.M., Cui H., Luijten E., Mao H.Q. // Adv. Mater. 2013. V. 25. № 2. P. 227-232.

100. Alexis F., Pridgen E., Molnar L.K., Farokhzad O.C. // Mol. Pharm. 2008. V. 5. № 4. P. 505-515.

101. Kim J., Kim P.H., Kim S.W.,Yun C.O. // Biomaterials. 2012. V. 33. № 6. P. $1838-1850$.

102. Ensign L.M., Schneider C., Suk J.S., Cone R., Hanes J. // Adv. Mater. 2012. V. 24. № 28. P. 3887-3894.

103. Lai S.K., Hida K., Shukair S., Wang Y.Y., Figueiredo A., Cone R., Hope T.J., Hanes J. // J. Virol. 2009. V. 83. № 21. P. 11196-11200.

104. McAuley J.L., Linden S.K., Png C.W., King R.M., Pennington H.L., Gendler S.J., Florin T.H., Hill G.R., Korolik V., McGuckin M.A. // J. Clin. Invest. 2007. V. 117. № 8. P. 2313-2324.

105. Jachak A., Lai S.K., Hida K., Suk J.S., Markovic N., Biswal S., 
Breysse P.N., Hanes J. // Nanotoxicology. 2012. V. 6. № 6. P. 614622.

106. Lai S.K., O'Hanlon D.E., Harrold S., Man S.T., Wang Y.Y., Cone R., Hanes J. // Proc. Natl. Acad. Sci. U. S. A. 2007. V. 104. № 5. P. $1482-1487$.

107. Olmsted S.S., Padgett J.L., Yudin A.I., Whaley K.J., Moench T.R., Cone R.A. // Biophys. J. 2001. V. 81. № 4. P. 1930-1937.

108. Lai S.K., Wang Y.Y., Hanes J. // Adv. Drug Deliv. Rev. 2009. V. 61. № 2. P. $158-171$.

109. Сu Y., Saltzman W.M. // Mol. Pharm. 2009. V. 6. № 1. P. 173-181.

110. Agafonov M., Volkova T., Kumeev R., Chibunova E., Terekhova I. // J. Mol. Liq. 2019. V. 274. P. 770-777.

111. Lai S.K., Suk J.S., Pace A., Wang Y.Y., Yang M., Mert O., Chen J., Kim J., Hanes J., // Biomaterials. 2011. V. 32. № 26. P. 6285-6290.

112. Suk J.S., Lai S.K., Wang Y.Y., Ensign L.M., Zeitlin P.L., Boyle M.P., Hanes J. // Biomaterials. 2009. V. 30. № 13. P. 2591-2597.

113. Mun E.A., Morrison P.W.J., Williams A.C., Khutoryanskiy V. V. // Mol. Pharm. 2014. V. 11. № 10. P. 3556-3564.

114. Irmukhametova G.S., Mun G.A., Khutoryanskiy V. V. // Langmuir. 
2011. V. 27. № 15. P. 9551-9556.

115. Xu Q., Boylan N.J., Suk J.S., Wang Y.Y., Nance E.A., Yang J.C., McDonnell P.J., Cone R.A., Duh E.J., Hanes J., // J. Control. Release. 2013. V. 167. № 1. P. 76-84.

116. Lautenschläger C., Schmidt C., Lehr C.M., Fischer D., Stallmach A. // Eur. J. Pharm. Biopharm. 2013. V. 85. №3 Pt A. P. 578-586.

117. Casettari L., Vllasaliu D., Castagnino E., Stolnik S., Howdle S., Illum L. // Prog. Polym. Sci. 2012. V. 37. № 5. P. 659-685.

118. Sogias I.A., Khutoryanskiy V. V., Williams A.C. // Macromol. Chem. Phys. 2010. V. 211. № 4. P. 426-433.

119. Ways T.M.M. PhD thesis. Reading, United Kingdom: University of Reading, 2019.

120. Bae K.H., Moon C.W., Lee Y., Park T.G. // Pharm. Res. 2009. V. 26. № 1. P. 93-100.

121. Yang X., Zhang Q., Wang Y., Chen H., Zhang H., Gao F., Liu L. // Colloids Surfaces B Biointerfaces. 2008. V. 61. № 2. P. 125-131.

122. Jiang X., Dai H., Leong K.W., Goh S.H., Mao H.Q., Yang Y.Y. // J. Gene Med. 2006. V. 8. № 4. P. 477-487.

123. Merkel O.M., Librizzi D., Pfestroff A., Schurrat T., Buyens K., 
Sanders N.N., De Smedt S.C., Béhé M., Kissel T. // J. Control.

Release. 2009. V. 138. № 2. P. 148-159.

124. Itaka K., Yamauchi K., Harada A., Nakamura K., Kawaguchi H., Kataoka K. // Biomaterials. 2003. V. 24. № 24. P. 4495-4506..

125. Alibolandi M., Abnous K., Anvari S., Mohammadi M., Ramezani M., Taghdisi S.M. // Artif. Cells. Nanomedicine. Biotechnol. 2018. V. 46. Sup.1. P. 1159-1169.

126. Shin J.M., Oh S.J., Kwon S., Deepagan V.G., Lee M., Song S.H., Lee H.J., Kim S., Song K.H., Kim T.W., Park J.H. // J. Control. Release. 2017. V. 267. P. 181-190.

127. Lele B.S., Hoffman A.S. // J. Control. Release. 2000. V. 69. № 2. P. 237-248.

128. Greenwald R.B., Gilbert C.W., Pendri A., Conover C.D., Xia J., Martinez A. // J. Med. Chem. 1996. V. 39. № 2. P. 424-431.

129. Zalipsky S. // Bioconjug. Chem. 1995. V. 6. № 2. P. 150-165.

130. Greenwald R.B., Pendri A., Conover C., Gilbert C., Yang R., Xia J. // J. Med. Chem. 1996. V. 39. № 10. P. 1938-1940.

131. Li C., Wallace S. // Adv. Drug Deliv. Rev. 2008. V. 60. № 8. P. 886898. 
132. Posey J.A. // Clin. Cancer Res. 2005. V. 11. № 21. P. 7866-7871.

133. Kelland L. // Expert Opin. Investig. Drugs. 2006. V. 15. № 11. P. $1309-1318$.

134. Li W., Zhan P., De Clercq E., Lou H., Liu X. // Prog. Polym. Sci. 2013. V. 38. № 3-4. P. 421-444.

135. Ahuja A., Khar R.K., Ali J. // Drug Dev. Ind. Pharm. 1997. V. 23. № 5. P. 489-515.

136. Heath F., Newman A., Clementi C., Pasut G., Lin H., Stephens G.J., Whalley B.J., Osborn H.M.I., Greco F. // Polym. Chem. 2016. V. 7. № 47. P. 7204-7210.

137. Naloxegol (Movantik) for Opioid-Induced Constipation. JAMA. 2016. V. 315, № 2. P. 194. 